\title{
The Role of Human Capital in Economic Growth
}

\author{
Derviş Boztosun, Semra Aksoylu, Zübeyde Şentürk Ulucak \\ Erciyes University, Kayseri, Turkey
}

\begin{abstract}
In endogenous growth theories, with the endogeneity of technology and its inclusion into the model, the new technologies produced by individuals equipped with knowledge, skills, and experience by using this technology were regarded as the human capital investments of countries. Later, the effects of human capital on economic growth became a significant topic in the empirical literature. In this study, initially the basic approaches to human capital were theoretically investigated. Then, the relationships between human capital and economic growth were analyzed with cointegration and causality tests by using the data of Turkey for the period 1961-2011. Our findings revealed a dual causality relationship between human capital and economic growth variables.
\end{abstract}

Keywords: human capital, economic growth, cointegration with structural break

\section{Introduction}

Economic growth in its simplest form is defined in the economics literature as the increase in goods and services produced in a country. It is also defined as a continuous increase in gross domestic product per capita. Such growth is an indicator of the development level desired by every country in an internationaly competitive environment. Labor is a production factor used to improve economic growth through the production of goods and services. Investments in labor improve the productivity of human capital. The knowledge, skills, experience, and similar assets of individuals significantly affect production factors through labor and accelerate economic growth (Koç, 2013). In this way, every supplementary asset to labor speeds up economic growth.

The theory of human capital regards the individual not only as a component of the production function but also as a dynamic input in the realization of economic progress (Özşahin \& Karaçor, 2013). Such dynamism attributed to the individual represents the knowledge and technology factors in economic growth models. There are several studies in the literature which investigate the relationships between human capital and economic growth from various aspects. Considering the basis of economic growth models, it was observed that Smith and Ricardo-like economists were the pioneers of classical growth theories. They investigated the growth processes of countries and provided significant contributions to the relevant literature.

In a neo-classical growth model, Solow (1956) considered technology as an external factor and did not explain the emergence of technology in his model. Later, technology was included in economic models as an

Derviş Boztosun, associate professor, Colleges of Applied Sciences, Erciyes University, Kayseri, Turkey.

Semra Aksoylu, associate professor, Colleges of Applied Sciences, Erciyes University, Kayseri, Turkey.

Zübeyde Şentürk Ulucak, research assistant, Faculty of Economics and Administrative Sciences, Erciyes University, Kayseri, Turkey.

Correspondence concerning this article should be addressed to Zübeyde Şentürk Ulucak, Erciyes Universty, Iktisadi ve Idari Bilimler Fakultesi, Iktisat Bolumu, Kayseri, Turkey. 
endogenous factor and the significance of human capital using information was proposed (Taban \& Kar, 2006). In internal growth models, Romer (1986; 1990), Lucas (1988), and later economists investigated economic growth through physical and human capital accumulation. Besides labor and capital, human capital had a significant place in endogenous growth models and additionally the effects of human capital on economic growth were pointed out in previous studies in the literature (Telatar \& Terzi, 2010).

The present study was conducted to assess the relationships between human capital and economic growth by means of human capital index data. Initially, the concept of human capital was defined and the relations with economic growth were pointed out. Then, theoretical and empirical studies were provided about the subject. In the practical section, the human capital index data of Turkey covering the period between 1961-2011 were used to analyze the relationships between human capital and economic growth with cointegration and causality tests. Finally, the results were discussed with the findings of earlier researchers.

\section{The Concept of Human Capital}

Businesses use three types of capital: physical capital (factory, stocks etc.), financial capital (investments), and intellectual capital. The very last one, intellectual capital, is defined as "nonfinancial fixed assets-intangible assets". Human capital is a component of intellectual capital. It represents the investments made on humans and encompasses human-related factors like knowledge, skills, experience, sufficiency, business quality, employee relations, emotional intelligence, entrepreneurialism, flexibility, employee loyalty, employee satisfaction, education, and creativity. In businesses, investment on humans is the most difficult investment to control.

The equivalent of human capital in the economy is labor, which is among the production factors and operates in order to earn. The individual should produce a good or a service to earn this wage. The knowledge, experience, and similar qualifications used in producing this good or service constitute the individual's gears and such gears were termed as human capital until the end of the 1950s (Bal, 2011). However, the focus herein is not only the physical power of the individual but also the knowledge, experience, analytical thinking ability, and similar intangible values. Later, human capital was defined not only as the power spent in the production of a good or service, but also as the qualifications of the individual.

Romer (1990) regarded human capital as the source of economic efficiency. The OECD (Organisation for Economic Co-operation and Developmen) defines human capital as the contributions of knowledge and skills made by an individual to a country's economy and thus as the improvement in social and economic development made by an individual (Eser \& Gökmen, 2009). Human capital can then briefly be defined as the contributions of individuals and every kind of knowledge and experience gained by an individual.

Since human capital is accepted as the qualifications acquired by individuals, in other words, the dynamic of the economy, these qualifications can be summarized as all kinds of knowledge and experiences which improve production (Karataş \& Çankaya, 2010). Human capital material is directly proportional to the country's economy. However, it may be misleading to link the efficiency of human capital only to the increase in a country's population. In fact, the quantitative traits of the population come into prominence in developing countries, while knowledge, skills, experience, and education-like qualitative traits come into prominence in developed countries. When we consider the situation today, it is easy to see that not the countries with a large population, but those with educated, healthy, and long-living individuals are more developed (Yumuşak, 2008). Such traits indicate that a large population alone is not sufficient for the efficiency of human capital. 
Throughout the world in the mid-20th century, especially after the Second World War, an educated labor force became a significant issue with countries' conversion into knowledgeable societies and countries assigned as much significance to human capital as they did to physical and financial capital (Doğan \& Şanli, 2003). Although Malthus's thesis "Increase in population reduces the income per capita" established a presence in neo-classical theory, later this thesis was abandoned since high-tech developments increased the income per capita despite the increasing population (Deliktaş, 2001). Kremer (1993) regarded the technological process as an increasing function of the population and adapted the principle of "the higher the population, the higher the number of people there will be to invent new technologies and the higher the knowledge gain will be" (Kremer, 1993, p. 712). Such an opinion was approved by others with the contributions made by technology to a country's economy.

Lucas (1988) pointed out the observable effects of both human capital and physical-financial capital on economic models. The author also pointed out that individuals should spend time on various activities to improve their performance and individual skills, a recommendation that is commonly mentioned in human capital theory (Lucas, 1988). Despite different definitions of human capital, the generally accepted definition encompasses every kind of individual-oriented knowledge and experience.

\section{Human Capital and Economic Growth Relations}

The outcomes of empirical studies and technological innovations have resulted in directing tremendous energy to human capital. In all countries with successful permanent growth, education, and training have allowed countries to overcome the changes in production methods and to improve human capital (Becker, 1993). Thus, every kind of investment made on human capital can also be viewed as a contribution to a country's economy.

While explaining economic growth, neo-classical theorists accepted technology and human capital as exogenous factors (Kar \& Ağır, 2006). Later on, neo-classical theory supported the hypothesis of "technological developments eliminated the problems which resulted from population increase and the population even positively affected economic development" (Güneş, 2005). Inclusion of human capital into economic growth models was started by Romer (1986). Contrary to the neo-classical growth model, Romer (1986) included technology into the endogenous growth model and thus endogenized technology. Romer (1990) then endogenized technology and included human capital into the model. Lucas (1988) developed a dynamic to define the technology variable and defined this dynamic as human capital in the model. Romer (1990) regarded technology as the outcome of individual abilities to obtain new products with new ideas and then included human capital accordingly. Additionally, Lucas (1988) included human capital into the model as the qualification levels of individuals (Ulucak, 2015).

Endogenous growth models instead focus on the quality of the population and accept the primary determinants of economic growth as either a direct increase in human capital or indirect activities of human capital like R\&D activities. Economic success provides significant contributions to investments, primarily to human capital, and also increases economic efficiency and productivity (Tsen, 2006). Positive economic developments ensure more qualified human capital. As one can see, although the direction of interaction between economic growth and human capital differs most of the time, their attraction to each other is always the same. While the positive attributes of human capital, namely, the implementation of knowledge and technology, affect economic growth, positive developments in the economy affect the quality of human capital (Genç, Değer, \& Berber, 2009). 
The investments made on human capital are highly significant in terms of economic competition among countries. In fact, the components which make some countries more prominent than others include any kind of supplements to inparticular, labor, which is a production factor. Countries with a qualified labor force integrate this force with advanced technology and thus experience the advantage of always being one step ahead in competition. In this way, increasing efficiencies in human capital provide significant contributions to a country's economy (Çakmak \& Gümüş, 2005).

Previous studies and experiences revealed that economic growth could not be achieved by only improving physical conditions. Additionally, the knowledge and skills acquired by the working and producing individual should also be accepted as a tool for economic progress. Likewise, Becker, Murpy, and Tamura (1990) in a study titled "Human Capital, Fertility and Economic Growth", indicated higher returns of human capital and education in developed countries than in developing countries. Based upon the aforementioned information, one can see that the size of a population alone is not sufficiently effective on economic growth and the bottom line is the knowledge, skills, and experience-like attributes of the population.

\section{Literature Review}

The research on human capital was started by Lucas (1998) and Romer (1986) with the inclusion of human capital into their models and the research continues today. Schultz (1961) differentiated human capital from the traditional perception of capital and accepted it as knowledge investment made on humans and indicated that a labor force which is not enriched with knowledge would not provide any contributions to economic growth in modern economies.

Benhabib and Spiegel (1994) investigated the role of human capital in economic growth and reported the positive impacts of physical and human capital on economic growth. Sacerdoti, Brunschwig, and Tang (1998), in a study carried out in Western Africa, investigated the effects of human capital on economic growth and indicated that physical capital was more effective on economic growth than human capital. The studies indicated that the reason why human capital was not very effective was due to the lack of qualified and trained individuals who were able to use advanced technology in human capital.

Evans, Green, and Murinde (2002), in a study to investigate the effects of human capital and financial developments on economic growth, used the 21-year data of 82 countries. The researchers indicated that financial development was as effective as human capital in economic growth. Güneş (2005) analyzed the relationships between population increase and economic growth with cointegration and a vector error correction model. He indicated that population increase had a short-term impact on economic growth and the thesis of "population increase negatively affects the economic growth" was not valid for Turkey.

In a study pointing out the significance of human capital in an endogenous growth model, Taban and Kar (2006) used the causality test on annual data for Turkey covering the period within 1969-2001 and reported a positive and reciprocal relationship between human capital and economic growth. Kar and Ağır (2006) applied cointegration and causality tests on data within 1926-1994 to assess the relationships between human capital and economic growth. The researchers used the share of health and education expenses in income to indicate human capital and found a causality relationship between the variables.

Sarkar (2007), in his study, used the data of 92 countries covering the period of 1970-1987. He obtained similar results with Benhabib and Spiegel (1994) and indicated that human capital was effective and had positive effects both on the prevention of income injustice and on economic growth. Ljungberg and Nilsson 
(2009) carried out a study on the Swedish economy with data covering the period within 1870-2000 and investigated the relationship between human capital and economic growth with the Granger causality test. The researchers reported that human capital was a significant factor in the growth of the Swedish economy, but the effects of human capital with improved educational levels after the 1970s had relatively lower impacts on economic growth than expected.

Bucci and Torre (2009), in their study, analyzed the relationship between the change in population and income per capita and concluded that human capital had ambiguous effects on income per capita during the process of knowledge and skill formation. However, the population had both direct and indirect impacts on economic growth.

Altıntaş and Çetintaş (2010) used data in Turkey for the period of 1970-2007 and investigated the relationships among human capital, fixed capital, export and economic growth with cointegration and error correction methods and tested the long and short-term causality relationships between the variables. The researchers reported long-term significant positive relationships among human capital, fixed capital, and export and concluded that human capital resulted in economic growth in Turkey.

Şimşek and Kadılar (2010) tested the causality relationships among human capital accumulation, export and economic growth with cointegration and error correction methods. The researchers used real annual gross domestic product, real export and enrollment to higher education data for the 1960-2004 period in Turkey and concluded that on increase in export and human capital supported long-term growth and on increase in gross domestic product nurtured on increase in human capital.

\section{Empirical Study and Results}

In this study, the long-term relationships between human capital and the gross domestic product (GDP) of Turkey were analyzed for the period of 1961-2011. The human capital index created based on years of education and returns of education was used to represent human capital (HC); real GDP values were used to represent the GDP variable. The data for both variables were taken from the PWT (Penn World Tables) database.

For sound and reliable outcomes, the unit root content of the variables used in estimations should be analyzed. Structural breaks in tested series should also be taken into consideration because there may be breakpoint unit roots in data series and the resultant outcomes may be misleading when they are not taken into consideration. Therefore, tests were conducted in this study to identify structural breaks. To overcome such a problem, Lee and Strazicich (2003) expanded the minimum Lagrande multipliers (LM) unit root test introduced by Schmidt and Phillips (1992) to the literature. In the LM test, the null hypothesis can be formed by taking structural breaks into consideration. Two structural breaks (at level and trend) are also identified as endogenous. In this way, the number and dates of structural breaks and the presence of unit roots in series can be analyzed reliably. The results for the unit root test on HC and GDP variables are provided in Table 1.

The unit root tests revealed that both variables included a unit root. In this case, the stable state of the linear combination of these two variables should be identified through cointegration analysis. Cointegration analysis tests the stable nature of the linear combination of unstable series including a unit root. It is also used to assess long-term relations between series, to assess whether or not there is a long-term balance between series and to assess the synchronized operation of series. There are various approaches in the literature to test this relationship. Most of these approaches are based on the assumption that the nature of the cointegration 
vector is constant throughout the investigated period. However, micro economic variables in the long-run are evidently affected and vary due to factors like economic crises, technology shocks, political changes, variations in individual decision, and preferences. As was indicated by Perron (1989), such changes, also called structural breaks, should definitely be taken into consideration in analyses for reliable outcomes. Therefore, in this study, the cointegration test developed by Hatemi-J (2008) was used to take possible structural breaks into consideration and to get better and more reliable results. The cointegration test introduced the literature by Gregory and Hansen (1996) and allowance for one endogenous break among the investigated series was expanded to two endogenous breaks by Hatemi-J (2008). The method operates over model 1 by considering two structural breaks for the GDP and $\mathrm{HC}$ variables in long-term relations between the series as follows:

$$
G D P_{t}=\gamma_{0}+\gamma_{1} D_{1 t}+\gamma_{2} D_{2 t}+\beta_{1} H C_{t}+\beta_{1} H C_{t} D_{1 t}+\beta_{1} H C_{t} D_{2 t}+\varepsilon_{t}
$$

where $G D P_{t}$ is a dependent variable vector and $H C_{t}$ is an independent variable vector. In this model, the dummy variables were defined as follows if $\mathrm{t}>[\mathrm{n} \tau 1]$ then $D_{1 t}=1$, otherwise 0 ; if $\mathrm{t}>[\mathrm{n} \tau 2]$ then $D_{2 t}=1$, otherwise 0 . The terms $\tau 1$ and $\tau 2$ have a value within $0-1$ and represent the unknown parameters indicating structural break times. Hatemi-J (2008) formed the null and alternative hypothesis of the cointegration test as follows:

$\mathrm{H}_{0}$ : There is no cointegration between the variables.

$\mathrm{H}_{1}$ : There is cointegration between the variables.

Table 1

Results of Lee Strazicich Unit Root Test With Structural Breaks

\begin{tabular}{|c|c|c|c|c|c|c|c|c|}
\hline \multirow{2}{*}{ Variable } & \multirow{2}{*}{ Model } & \multirow{2}{*}{$\lambda$ value } & \multirow{2}{*}{ Number of lags } & \multirow{2}{*}{ Break dates } & \multirow{2}{*}{ Test statistics } & \multicolumn{3}{|c|}{ Critical values } \\
\hline & & & & & & $1 \%$ & $5 \%$ & $10 \%$ \\
\hline \multirow[b]{2}{*}{$\mathrm{HC}$} & Level & & 2 & $\begin{array}{l}1978 \\
1982 \\
\end{array}$ & -3.1649 & -4.54 & -3.84 & -3.50 \\
\hline & Level and trend & $\begin{array}{l}\lambda_{1}: 0.4 \\
\lambda_{2}: 0.6\end{array}$ & 2 & $\begin{array}{l}1979 \\
1992\end{array}$ & -5.4850 & -6.45 & -5.67 & -5.31 \\
\hline \multirow[b]{2}{*}{ GDP } & Level & & 1 & $\begin{array}{l}2002 \\
2007\end{array}$ & -1.8451 & -4.54 & -3.84 & -3.50 \\
\hline & Level and trend & $\begin{array}{l}\lambda_{1}: 0.4 \\
\lambda_{2}: 0.8\end{array}$ & 1 & $\begin{array}{l}1984 \\
1999\end{array}$ & -6.5070 & -6.42 & -5.65 & -5.32 \\
\hline
\end{tabular}

Hatemi-J (2008) used three different test statistics, namely, $A D F, Z_{a}$, and $Z_{t}$, to test the null hypothesis. $A D F$ tests the significance of the $\varepsilon_{t-1}$ parameter value through the regression of the first difference of the error term of model $1\left(\varepsilon_{t-1}\right)$ with $\Delta \varepsilon_{t-1} \ldots \Delta \varepsilon_{t-k}$ values. $Z_{a}$ and $Z_{t}$ are based on the deviation-adjusted first-order auto correlation coefficient $\left(\hat{\rho}^{*}\right)$ calculations and are defined as follows:

$$
\hat{\rho}^{*}=\frac{\sum_{t=1}^{n-1}\left(\hat{\varepsilon}_{t} \hat{\varepsilon}_{t+1}-\sum_{j}^{B} \omega\left(\frac{j}{B}\right) \hat{\vartheta}(j)\right)}{\sum_{t=1}^{n-1} \hat{\varepsilon}_{t}^{2}}
$$

where $\omega($.$) is the kernel weight function including standard conditions for spectral intensity estimators. The$ symbol $B$ yields the band width meeting the conditions of $B \rightarrow \infty$ and $B / n^{5}=O(1)$, and $\hat{\vartheta}(j)$ yields the autocovariance function. Then, the autocovariance function is defined by

$$
\hat{\vartheta}(j)=\frac{1}{n} \sum_{t=j+1}^{T}\left(\hat{\varepsilon}_{t-j} \hat{\rho} \hat{\varepsilon}_{t-j-1}\right)\left(\hat{\varepsilon}_{t} \hat{\rho} \hat{\varepsilon}_{t-1}\right)
$$

where the $Z_{a}$ and $Z_{t}$ test statistics were calculated as defined below 


$$
\begin{gathered}
Z_{a}=n\left(\hat{\rho}^{*}-1\right) \\
Z_{t}=\frac{\left(\hat{\rho}^{*}-1\right)}{\left(\hat{\vartheta}(0)+2 \sum_{j=1}^{B} \omega(j / B) \hat{\vartheta}(j)\right) / \sum_{1}^{n-1} \hat{\varepsilon}_{t}^{2}}
\end{gathered}
$$

In accordance with the defined test statistics, the Hatemi-J (2008) cointegration test results calculated for model 1 are provided in Table 2 .

Table 2

Hatemi-J (2008) Cointegration Test Results

\begin{tabular}{llllll}
\hline \multirow{2}{*}{ Test statistics } & \multirow{2}{*}{ Break years } & Calculated value & \multicolumn{3}{c}{ Critical values } \\
\cline { 4 - 6 } & & & $1 \%$ & $5 \%$ & $10 \%$ \\
\hline$A D F^{*}$ & $1981-1990$ & -6.0070 & -6.503 & -6.015 & -5.653 \\
$Z_{t}^{*}$ & $1980-1995$ & -7.6586 & -6.503 & -6.015 & -5.653 \\
$Z_{a}^{*}$ & $1980-1995$ & -121.1133 & -90.794 & -76.003 & -52.232 \\
\hline
\end{tabular}

(The Gauss codes written by Hatemi-J were used)

The calculated test statistics are given on the left side of the critical values on the table. Therefore, the null hypothesis indicating "there is no cointegration between the variables" was rejected and it was decided that there is a long-term cointegration between the variables, in other words, variables in the long-run exhibited synchronous action.

Causality analysis between the variables is another critical issue. The causality test recommended by Hacker and Hatemi-J (2006) is both a newer method and uses the bootstrap technique allowing calculation of critical values in accordance with the data set used in the study. Therefore, the method was regarded as a more reliable method. Since Hacker and Hatemi-J (2006) causality test produces proper critical values for the data set through the bootstrap technique, it can yield more efficient outcomes for analysis with low observations (Hacker \& Hatemi-J, 2006). Again, since this method is developed based on Toda and Yamamoto's (1995) MWALD (Modified Wald test) test, it is not sensitive against the integration level of the series. Toda and Yamamoto (1995) recommended the modified MWALD test assuming the normal distribution of the error term and asymptotic chi-square distribution of the test statistics to test the null hypothesis of "no-Granger causality".

$$
M W A L D=(C \widehat{\beta})\left[C\left(\left(Z^{\prime} Z\right)^{-1} \oplus S_{U}\right) C^{\prime}\right]^{-1}(C \widehat{\beta})
$$

where $\oplus$ indicates the Kronecker multiplier, $C$ indicates the $p \times n(1+n(p+d))$ matrix, $S_{U}$ indicates the variance covariance matrix of the error term of the model, and $\hat{\beta}$ indicates the column stacking processor. The null hypothesis of the test indicates "no-Granger causality" as expressed below

$$
H_{0}: C \beta=0
$$

Hacker and Hatemi-J (2006) approach calculates the critical values for this hypothesis by using the bootstrap technique. The critical values calculated with this method and test statistics are provided in Table 3 .

The results provided in Table 3 indicate that the null hypothesis for both cases is rejected. In this case, the causality analysis results indicate that the changes in GDP were the reason for the changes in HC and vice versa. Therefore, there was a dual causality relationship between the variables.

The estimation of long-term cointegration parameters in which human capital was taken as an explanatory variable, and the calculation of their effects on the dependent variable are other critical issues. When the OLS 
(Ordinary Least Squares) estimator is used without the performance of relevant corrections, the estimations will then be deviant and inconsistent because of autocorrelation and endogeneity problems (Montalvo, 1995). The FMOLS (Fully Modified Ordinary Least Squares) estimator of Phillips and Hansen (1990), the CCR (Canonical Cointegration Regression) estimator of Park (1992), and the DOLS (Dynamic Ordinary Least Squares) estimator of Stock and Watson (1993) take these corrections into consideration; therefore they are commonly used as cointegration estimators. In this study, the long-term cointegration parameters were separately estimated by using these estimators. The estimation results calculated by using the logarithmic values of the variables are provided in Table 4. In this way, coefficients were able to be interpreted as having flexibility.

Table 3

\section{Causality Test Results}

\begin{tabular}{lllll}
\hline Hypothesis & Test statistics & $\begin{array}{l}\text { Bootstrap critical value } \\
1 \%\end{array}$ & $\begin{array}{l}\text { Bootstrap critical value } \\
5 \%\end{array}$ & $\begin{array}{l}\text { Bootstrap critical value } \\
10 \%\end{array}$ \\
\hline GDP $\neq>$ HC & 7.791 & 7.353 & 4.096 & 2.824 \\
HC $\neq>$ GDP & 7.524 & 7.294 & 4.059 & 2.808 \\
\hline
\end{tabular}

(The Gauss codes written by Hacker and Hatemi-J were used)

Table 4

Long-Term Cointegration Parameters

\begin{tabular}{|c|c|c|c|c|}
\hline & OLS & FMOLS & DOLS & CCR \\
\hline \multirow{3}{*}{ LHC } & 2.907097 & 3.216245 & 3.418860 & 3.215854 \\
\hline & $(0.3135)$ & $(0.1179)$ & $(0.0546)$ & $(0.1170)$ \\
\hline & {$[0.0000]$} & {$[0.0000]$} & {$[0.0000]$} & {$[0.0000]$} \\
\hline \multirow{3}{*}{ Sabit } & 11.17190 & 10.92499 & 10.52832 & 10.92434 \\
\hline & $(0.2357)$ & $(0.0703)$ & $(0.0571)$ & $(0.0666)$ \\
\hline & {$[0.0000]$} & {$[0.0000]$} & {$[0.0000]$} & {$[0.0000]$} \\
\hline$\overline{\mathrm{R}^{2}}$ & 0.995411 & 0.979751 & 0.996425 & 0.979727 \\
\hline
\end{tabular}

Notes. The values in parentheses indicate standard errors; the values in brackets indicate probability values.

The first column in Table 4 presents the results obtained with the OLS estimator. The autocorrelation problem in OLS estimation was solved by including the AR(1) process into the model. However, if there is an endogeneity problem, then the results are deviant and inconsistent. The other estimators do not have such problems. Therefore, the results obtained with FMOLS, DOLS, and CCR are more reliable. After all, OLS estimations were different from the other estimations and had higher standard errors. The FMOLS and CCR estimators yielded almost identical results. The results obtained from all the estimators had the uppermost significance levels. The least standard error was observed in the DOLS estimator. According to the DOLS result, a 1\% increase in human capital yielded about a 3.2\% increase in GDP.

\section{Conclusion}

In this study, the significance of human capital in endogenous growth theories was pointed out and the effects of labor enriched with knowledge and skills on economic growth were obtained. In modern economies, developed countries have established their place in international competition not with the quantitative wealth of their human capital but with highly qualified and educated individuals. Therefore, the relationship between economic growth and human capital has been the topic of several studies. In the present study, the relationship 
between economic growth and human capital was empirically analyzed and a long-term cointegration relationship was observed between these two variables. The findings of the present study revealed that these variables acted synchronously in the long-run and there was a balanced relationship between them. Another outcome of this study was the presence of a dual causality relationship between the variables. Such an outcome can be interpreted as follows: an increase in human capital was responsible for increased incomes in Turkey and vice versa. According to long-term cointegration parameters in which HC was used as the explanatory variable, a $1 \%$ increase in human capital yielded about a 3.2\% increase in GDP. Accordingly, the cost fractions spent to increase the human capital level in the long-run result in more than a 3-fold increase in GDP. Such a case revealed that politicians searching solutions for growth and development should never hesitate to take steps to improve human capital levels.

\section{References}

Altıntaş, H., \& Çetintaş, H. (2010). Türkiye'de ekonomik büyüme, beşeri sermaye ve ihracat arasındaki ilişkilerin ekonometrik analizi: 1970-2005. Erciyes Üniversitesi İ.I.B.F. Dergisi, 36, 33-56.

Bal, O. (2011). Beşeri Sermaye ve Ekonomik Gelişme. Uluslararası Bilgi, Ekonomi ve Yönetim Kongresi. Retrieved from http://akademikpersonel.kocaeli.edu.tr/oguz.bal/bildiri/oguz.bal21.09.2011_19.09.22bildiri.pdf

Becker, G. S. (1993). Human Capital (3rd ed.). Chicago and London: The University Chicago Press.

Becker, G. S., Murphy, K. M., \& Tamura, R. (1990). Human capital, fertility, and economic growth. The Journal of Political Economy, (October), Part. 2: The Problem of Development: A Conference of the Institute for the Study of Free Enterprise Systems, 98(5), 12-37.

Benhabib, J., \& Spiegel, M. M. (1994). The role of human capital in economic development evidence from aggregate cross-country data. Journal of Monetary Economics, 34, 143-173.

Bucci, A., \& La Torre, D. (2009). Population and economic growth with human and physical capital investments. Int Rev Econ, Springer, 56, 17-27.

Çakmak, E., \& Gümüş, S. (2005). Türkiye'de beşeri sermaye ve ekonomik büyüme: Ekonometrik bir analiz (1960-2002). Ankara Üniversitesi SBF Dergisi, 60(1), 59-72.

Deliktaş, E. (2001). Malthusgil yaklaşımdan modern ekonomik büyümeye. Ege Akademik Bakış, 1(1), 1-19.

Doğan, S., \& Şanli, D. (2003). İktisadi kalkınmada beşeri sermaye. Süleyman Demirel Üniversitesi İ.I.B.F. Dergisi, 8(1), $173-196$.

Eser, K., \& Ekiz Gökmen, Ç. (2009). Beşeri sermayenin ekonomik gelişme üzerindeki etkileri: Dünya deneyimi ve Türkiye üzerine gözlemler. Sosyal ve Beşeri Bilimler Dergisi, 1(2), 41-56.

Evans, A. D., Green, C. J., \& Murinde, V. (2002). Human capital and financial development in economic growth: New evidence using the translog production function. International Journal of Finance and Economics, Int. J. Fin. Econ. 7, 123-140.

Genç, M. C., Değer, M. K., \& Berber, M. (2009). Beşeri sermaye, ihracat ve ekonomik büyüme: Türkiye ekonomisi üzerine nedensellik analizi. Uluslar Arası 7. Bilgi, Ekonomi ve Yönetim Kongresi Bildiriler Kitabı, 48-60.

Gregory, A. W., \& Hansen, B. E. (1996). Residual-based tests for cointegration in models with regime shifts. Journol of Econometrics, 70, 99-126.

Güneş, Ş. (2005). Türkiye'de nüfus artışının ekonomik büyümeyle ilişkisi üzerine ekonometrik bir analiz. Ankara Üniversitesi SBF Dergisi, 60(3), 123-136.

Hacker, R. S., \& Hatemi, J. A. (2006). Tests for causality between integrated variables using asymptotic and bootstrap distributions: Theory and application. Applied Economics, 38, 1489-1500.

Hatemi-J, A. (2008). Tests for cointegration with two unknown regime shifts with an application to financial market integration. Empirical Economics, 35, 497-505.

Montalvo, J. G. (1995). Comparing cointegration regression estimators: Some additional Monte Carlo results. Economic Letters, 48, 229-234.

Kar, M., \& Ağır, H. (2006). Türkiye'de beşeri sermaye ve ekonomik büyüme ilişkisi: Eşbütünleşme yaklaşımı ile nedensellik testi, 1926-1994. Selçuk Üniversitesi, I.I.B.F. Sosyal ve Ekonomik Araştırmalar Dergisi, 6(11), 51-68.

Karataş, M., \& Çankaya, E. (2010). İktisadi kalkınma sürecinde beşeri sermayeye ilişkin bir inceleme. Mehmet Akif Ersoy Üniversitesi Sosyal Bilimler Enstitüsü Dergisi, 2(3), 29-55. 
Koç, A. (2013). Beşeri sermaye ve ekonomik büyüme ilişkisi: Yatay kesit analizi ile AB ülkeleri üzerine bir değerlendirme. Maliye Dergisi (Temmuz-Aralı), 165, 241-258.

Kremer, M. (1993). Population growth and technological change: One million B.C. to 1990. The Quarterly Journal of Economics, $108(3), 681-716$.

Lee, J., \& Strazicich, M. C. (2003). Minimum lagrange multiplier unit root test with two structural breaks. The Review of Economics and Statistic, 85(4), 1082-1089.

Ljungberg, J., \& Nilsson, A. (2009). Human capital and economic growth: Sweden 1870-2000. Cliometrica, 3, 71-95.

Lucas, R. E. (1988). On the mechanics of economic development. Journal of Monetary Economics, 22, 3-42.

Özşahin, Ş., \& Karaçor, Z. (2013). Ekonomik büyümenin belirleyicilerinden biri olarak beşeri sermaye: Yükseköğrenimin türkiye ekonomisi için önemi. Niğde Üniversitesi İ̈BF Dergisi, 6(1), 148-162.

Park, J. (1992). Canonical cointegrating regressions. Econometrica, 60, 119-143.

Perron, P. (1989). The great crash, the oil price shock and the unit root hypothesis. Econometrica, 57, 1361-1401.

Phillips, P. C. B., \& Hansen, B. E. (1990). Statistical inference in instrumental variables regressions with i(1) processes. Review of Economic Studies, 57, 99-125.

Romer, P. M. (1986). Increasing returns and long run growth. Journal of Political Economy, 94(5), 1002-1037.

Romer, P. M. (1990). Endogenous technological change. Journal of Political Economy, 98(5), 71-102.

Sacerdoti, E., Brunschwig, S., \& Tang, J. (1998). The impact of human capital on growth: Evidence from west Africa. International Monetary Fund, African Department (IMF Working Paper), WP/98/162 (November), 1-34. Retrieved from https://www.imf.org/external/pubs/ft/wp/wp98162.pdf

Sarkar, D. (2007). The role of human capital in economic growth revisited. Applied Economics Letters, 14(6), 419-423.

Schmidt, P., \& Phillips, P. C. B. (1992). LM tests for a unit root in the presence of deterministic trends. Oxford Bulletin of Economics and Statistics, 54(3), 257-287.

Schultz, T. W. (1961). Investment in human capital. The American Economic Review, 51(1), 1-16.

Solow, R. (1956). A contribution to the theory of economic growth. Quarterly Journal of Economics, 70(1), 65-94.

Stock, J. H., \& Watson, M. (1993). A simple estimator of cointegrating vectors in higher order integrated systems. Econometrica, 61, 783-820.

Şimşek, M., \& Kadılar, C. (2010). Türkiye'de beşeri sermaye, ihracat ve ekonomik büyüme arasındaki ilişkinin nedensellik analizi. Cumhuriyet Üniversitesi I.I.I.B.F. Dergisi, 11(1), 115-140.

Taban, S., \& Kar, M. (2006). Beşeri sermaye ve ekonomik büyüme: Nedensellik analizi 1969-2001. Anadolu Üniversitesi Sosyal Bilimler Dergisi, 6(1), 159-182.

Telatar, O. M., \& Terzi, H. (2010). Nüfus ve eğitimin ekonomik büyümeye etkisi: Türkiye üzerine bir inceleme. Atatürk Üniversitesi I.I.I.B.F Dergisi, 24(2), 197-214.

Toda, H. Y., \& Yamamoto, T. (1995). Statistical inference in vector autoregressions with possibly integrated processes. Journal of Econometrics, 66, 225-250.

Tsen, W. H. (2006). Granger causality tests among openness to international trade, human capital accumulation and economic growth in China: 1952-1999. International Economic Journal, 20(3), 285-302.

Ulucak, R. (2015). The environment in economic growth models: An application based on ecological footprint (Unpublished doctoral thesis, Erciyes University, Social Sciences Institute) (in Turkish).

Yumuşak, İ. G. (2008). Beşeri sermayenin iktisadi önemi ve türkiye'nin beşeri sermaye potansiyeli. Sosyal Siyaset Konferansları Dergisi, 55, 3-48. 